\title{
Punching Shear Behavior under Sustained Load
}

\author{
Sevket Ozden, Hakan Erdogan, and Erkan Akpinar
}

\begin{abstract}
This paper presents an experimental research program focused on the punching strength of flat-plate test specimens under the effect of sustained load. Two identical $2 / 3$ scaled test specimens were loaded up to different sustained load levels for 270 days and the change in the crack width and propagation were monitored. After 270 days, these two specimens were loaded up to failure. The punching strengths of those specimens were compared with the identical control specimen that kept unloaded in the same environment.
\end{abstract}

Index Terms-Flat plate, punching shear, sustained load

\section{INTRODUCTION}

Several reasons such as improper design and detailing, poor construction quality or change in structural use may result in unintentional increase in service loads on existing flat-plate type of structures. In addition, time dependent effects such as concrete deterioration and corrosion of steel, drying shrinkage and creep can also cause reduction in the performance of those structures. One of the vital deficiencies of flat plate type of structures is the possibility of punching failure in the slab-connection region due to excessive vertical shear.

Punching shear strength of flat-plates has been studied since the 1930s [1]-[5]. Moe [5] performed one of the pioneering study that focused on the several parameters that may possibly effect the shearing strength of reinforced concrete flat-plates under concentrated loads. Moe tested total of 43 flat-plate specimens, one of which was subjected to sustained load for three months and unloaded and loaded again up to failure to determine the long-term loading effect on punching strength of flat plates. There are also other studies [6]-[8] that mainly focused on the long-term cracking and deflection behavior of flat-plate structures.

In this study it was aimed to investigate the effect of long term ( 9 months) sustained loading on the punching strength of flat-plates. Contrary to traditional methods in which the load applied by a hydraulic jack, the sustained load was applied by mechanical post-tensioning method that may eliminate the possible errors caused by the hydraulic jack or load measuring device.

\section{EXPERIMENTAL PROGRAM}

\section{A. Design of Test Specimens}

Three reinforced concrete flat-plate specimens with

Manuscript received March 15, 2013; revised July 2, 2013.

The authors are with the Department of Civil Engineering, Okan University, İstanbul, Turkey (e-mail: sevketozden@yahoo.com, sevket.ozden@okan.edu.tr, ehakan80@hotmail.com, hakan.erdogan@kocaeli.edu.tr, akpinarerkan@yahoo.com, erkan.akpinar@ kocaeli.edu.tr). identical dimensions and reinforcement ratios were constructed. The geometrical details and reinforcement layout of the specimens were illustrated in Fig. 1.
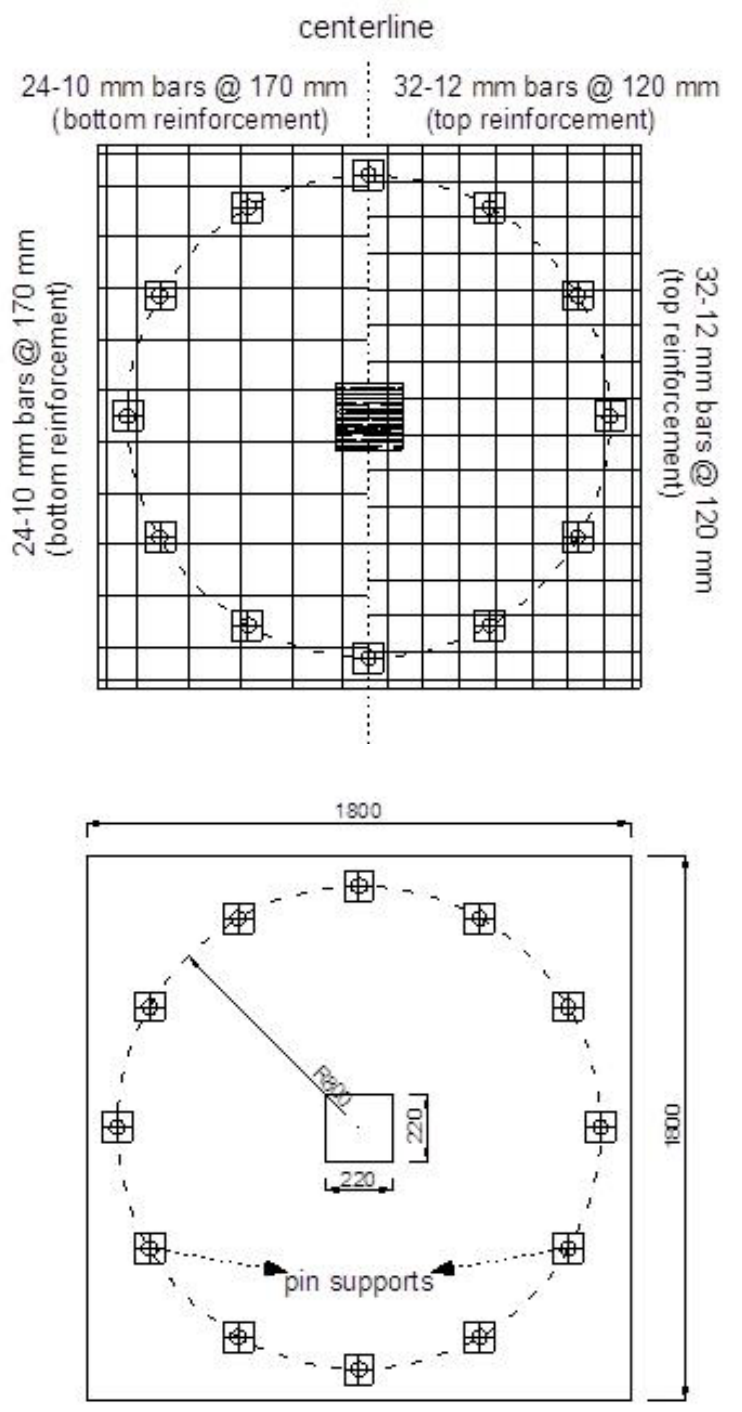

Fig. 1. Test specimen details and reinforcement layout

The specimens were designed to represent the $2 / 3$ scaled slab-column connection portion of a prototype flat-plate type of structure. The thickness and the effective depth of the specimens were equal to $130 \mathrm{~mm}$ and $100 \mathrm{~mm}$ respectively. The testing region was bounded by the slab contraflexure points where the theoretical moment assumed to be zero under vertical loading which is a commonly preferred testing method to minimize the specimen size.

\section{B. Test Setup and Loading History}

A commonly used testing setup in the literature was adopted in the experimental program. First, two circular steel tubes were placed on a prismatic rigid concrete block with depth of $500 \mathrm{~mm}$ to provide sufficient resistance for 
application of the load. Then, a rigid steel beam was set on the circular tubes as shown in Fig. 2. Finally, the specimen was seated on the spreader beam and connected to the rigid concrete block at the bottom via total of 12 high strength 18 $\mathrm{mm}$ rods positioned in a circular boundary of the slab. Contrary to general load application schemes by using hydraulic jack and measuring the applied load by a strain gauge induced load cell, the load was applied by post-tensioning in order to minimize the possible errors due to unexpected time-dependent pressure changes in hydraulic jack and deformation of the strain gage in the load-cell. A calibrated torque wrench was used for equally post-tensioning of 12 high-strength connection rods around the specimen boundary.

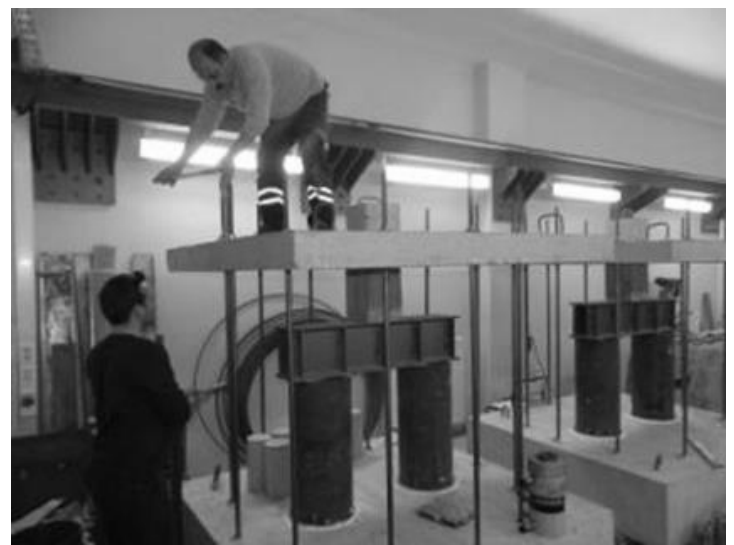

Fig. 2. General view of test setup and sustained load application

ACI 318-11 [9] defines the punching load of flat plates without any shear reinforcement as the smallest of three expressions given in Equation 1;

$$
V_{c}=\frac{1}{3} \sqrt{f_{c}^{\prime}} b_{o} d ; V_{c}=\left(\frac{1}{6}+\frac{1}{3 \beta}\right) \sqrt{f_{c}^{\prime}} b_{o} d ; V_{c}=\left(\frac{\alpha_{S} d}{12 . b_{o}}+\frac{1}{6}\right) \sqrt{f_{c}^{\prime}} b_{o} d
$$

where $f_{c}$ ' is the compressive strength of concrete, $b_{o}$ is the critical punching perimeter (located $d / 2$ away from the column face), $d$ is the effective depth, $\beta$ is the column aspect ratio, $\alpha$ is a coefficient depending on the column location (40 for interior columns).

Two identical test setups were prepared. At the age of 14 days after casting two identical specimens, PT01 and PT02, were loaded up to $50 \%$ and $85 \%$ of their capacities calculated by ACI provisions respectively. The high-strength connection rods were checked three times in a week and the loss in sustained load due to cracking of the specimens was restored by tightening the rods, it was aimed to keep the applied load constant in this way. Since, the load was applied mechanically without using any data acquisition system, no deflection is measured during long-term loading.

At the end of 270 days, a hydraulic jack with a capacity of $600 \mathrm{kN}$ and load cell of $1000 \mathrm{kN}$ was placed between the two circular steel tubes as shown in Fig. 3 to load the specimens up to failure. Additionally, the center-deflection of the specimens was also measured in order to determine the flexural rigidity of the specimens after application of sustained loading.

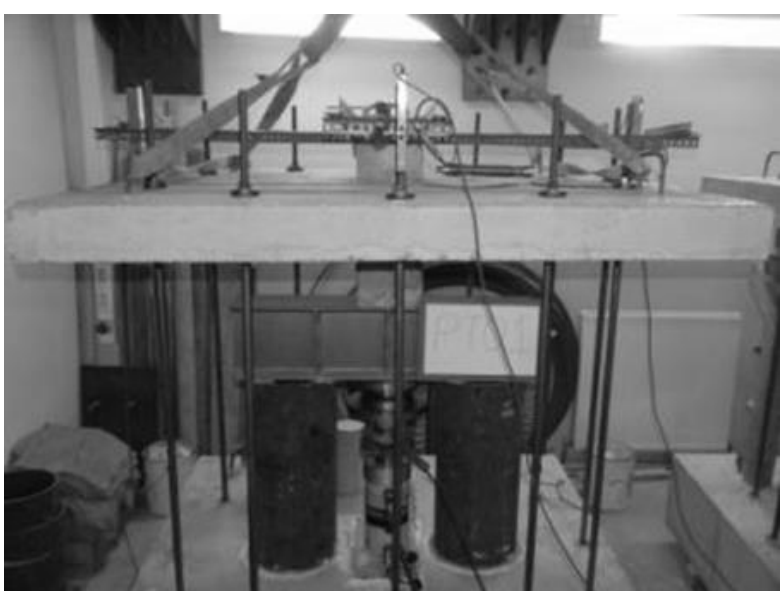

Fig. 3. Loading up to failure after 270 days

\section{Materials}

The concrete mixture was designed to have compressive strength of $30 \mathrm{MPa}$ at the age of 28 days. The results of cylinder test at different ages of concrete were given in Table I. The hot-rolled deformed reinforcing steel bars (having 10 and $12 \mathrm{~mm}$ diameters) were used to construct the top and bottom reinforcement mats of the test specimens. The yield strength of the steel bars was 465 and $481 \mathrm{MPa}$ respectively,

TABLE I: VARIATION OF CONCRETE STRENGTH BY TIME

\begin{tabular}{ccccc}
\hline \hline $\begin{array}{c}\text { Age of Concrete } \\
\text { (days) }\end{array}$ & 7 & 14 & 28 & 270 \\
\hline $\begin{array}{c}\text { Compressive } \\
\text { Strength } \\
\left(f_{c}{ }^{\prime}-\mathrm{MPa}\right)\end{array}$ & 21.3 & 26.5 & 28.1 & 29.84 \\
\hline \hline
\end{tabular}

\section{TEST RESULTS AND DISCUSSIONS}

\section{A. Crack Patterns and Measurements}

The variation of crack widths over time is displayed in Fig. 4. It is obvious from the graph that the maximum crack width measured on top face of the specimens has a tendency to increase up to $120^{\text {th }}$ day of loading. The remainder of the test, the change in maximum crack width is relatively small compared to rapid increase in first 120 days. Similar behavior was reported in the literature [6]. Fig. 5 shows the crack pattern on top face of the specimens under sustained load at the age of 270 days, just before loading up to failure.

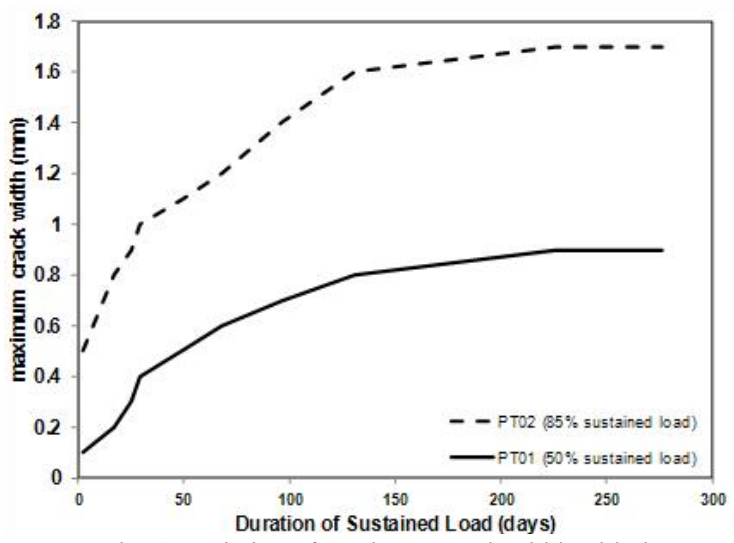

Fig. 4. Variation of maximum crack width with time 


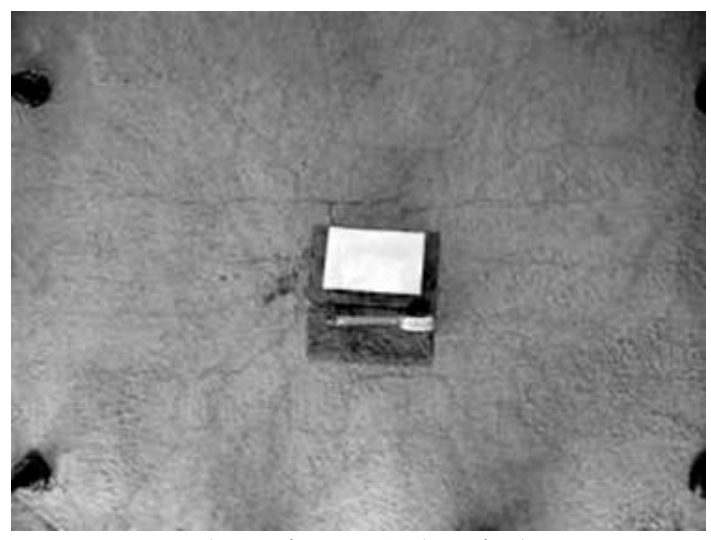

a) Specimen PT01 (top view)

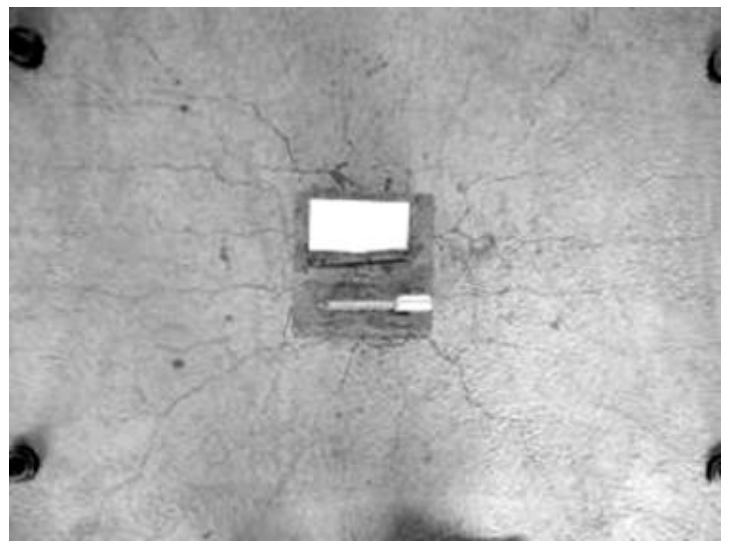

b) Specimen PT02 (top view)

Fig. 5. Crack patterns of specimens after 270 days under sustained load, just before loading to failure

\section{B. Load-Deflection Curves}

The load versus center deflection curves of the specimens (PT01 and PT02) recorded during post-loading stage (considering the end of sustained loading period till failure) is illustrated in Fig. 6 together with the load-center deflection curve of companion control specimen (CNT) without any sustained load. In Fig. 6, the load values are normalized with respect to punching design capacity computed by Eq. (1) which clearly indicates that the mechanical application of sustained load is satisfactory with negligible errors. Fig. 6 also indicates that application of sustained load has no significant effect on the punching strength of both specimens PT01 and PT02. The comparison of experimental capacities of specimens PT01 and PT02 with respect to design capacity of ACI 318-11 and capacity of control specimen CNT are given in Table II.

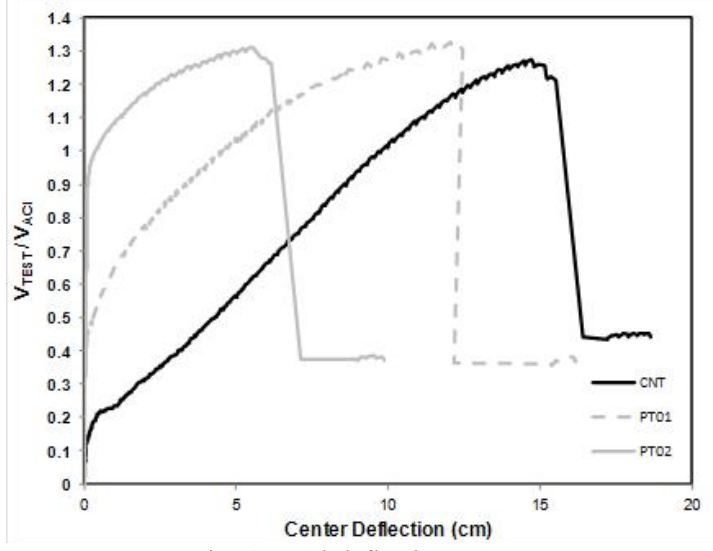

Fig. 6. Load-deflection curves
TABLE II: COMPARISON OF TEST RESULTS

\begin{tabular}{ccccccc}
\hline \hline Specimen & $\begin{array}{r}\mathrm{V}_{\mathrm{ACI}} \\
(\mathrm{kN})\end{array}$ & $\begin{array}{c}\mathrm{V}_{\mathrm{TEST}} \\
(\mathrm{kN})\end{array}$ & $\begin{array}{c}\mathrm{V}_{\text {SUS }} \\
(\mathrm{kN})\end{array}$ & $\begin{array}{c}\mathrm{V}_{\text {SUS }} / \\
\mathrm{V}_{\text {TEST }}\end{array}$ & $\begin{array}{c}\mathrm{V}_{\text {TEST }} / \\
\mathrm{V}_{\mathrm{ACI}}\end{array}$ & $\begin{array}{c}\mathrm{V}_{\text {TEST }} / \\
\mathrm{V}_{\mathrm{CNT}}\end{array}$ \\
\hline CNT & & 294.8 & 0 & 0 & 1.27 & 1.00 \\
PT01 & 231.4 & 307.9 & 106.4 & 0.35 & 1.33 & 1.04 \\
PT02 & & 303.5 & 204.5 & 0.65 & 1.31 & 1.03 \\
\hline \hline
\end{tabular}
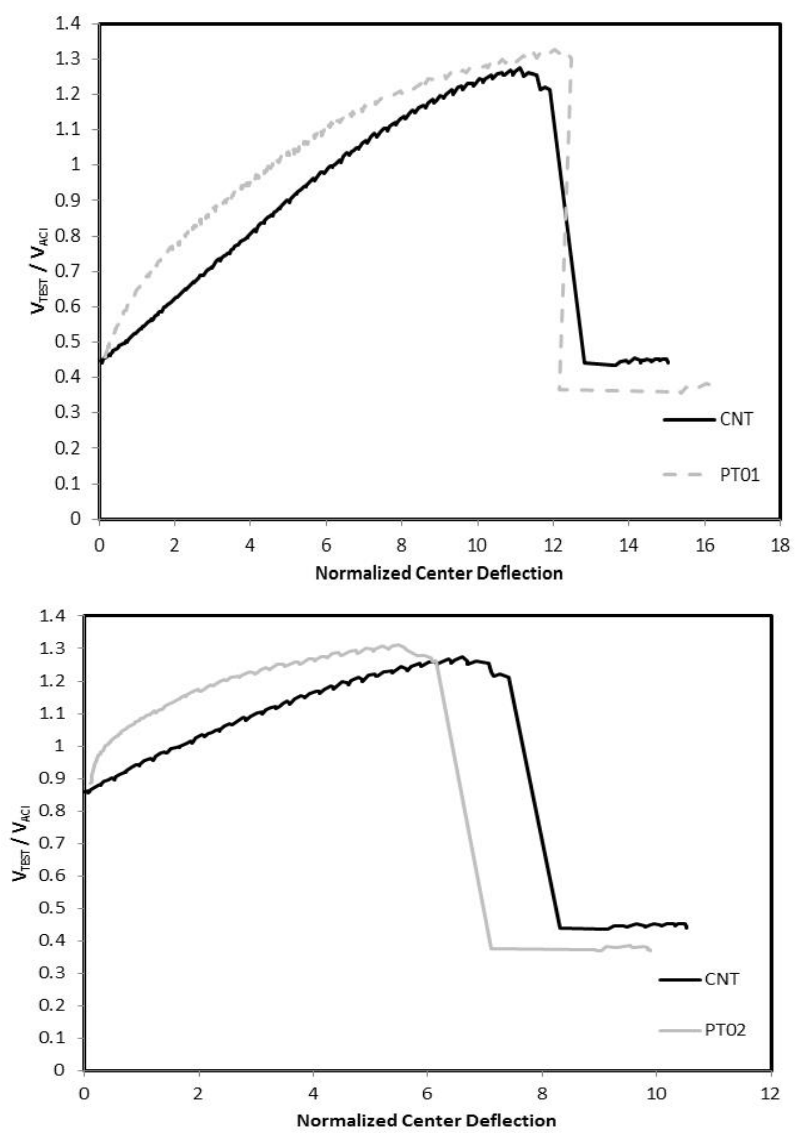

Fig. 7. Load vs normalized deflection curves for comparison of stiffness after sustained loading.

On the other hand, the center deflection values at failure load decreased significantly with increasing sustained load level for post-loading stage. This may be attributed to the cracking observed during sustained loading stage that reduced the deformability of the specimen when it is loaded to failure.

For comparison purposes and better understanding the effect of sustained load on post-loading stiffness of the specimens PT01 and PT02, the load-center deflection curve of control specimen CNT is shifted by equating the deflection values to zero that corresponding to the sustained load level for both specimens PT01 and PT02 separately as shown in Fig. 7. It is apparent from Fig. 7 that sustained loading and existence of cracks has no detrimental effect on the post-loading stiffness of the specimens. However, it should be noted that excessive cracking of the specimens under the effect of long-term sustain loading may lead to significant reduction in initial flexural rigidity of the specimens.

\section{CONCLUSION}

The sustained load and its variation had no significant 
effect on the punching load and post-loading stiffness of the identical test specimens. However, the deformation capacity of the connection at the time of failure load decreases with increasing sustained load level. The proposed mechanical load application scheme by post-tensioning the connection ties of the test setup appear to be applicable for sustained load testing of reinforced concrete structures.

\section{REFERENCES}

[1] O. Graf, "Strength tests of reinforced concrete slabs supported on all sides under concentrated loads," in German, Deutscher Ausschuss für Eisenbeton, pp. 26,1938.

[2] F. E. Richart and R.W. Kluge, "Tests on reinforced concrete slabs subjected to concentrated loads," Bulletin No.314. University of Illinois Engineering Experiment Station, vol. 36, no. 85, pp. 1-86, 1939.

[3] R. D. Elstner and E. Hognestad E. "Shearing strength of reinforced concrete slabs," ACI Journal, vol. 53, no. 1, pp. 29-58, 1956

[4] C. S. Whitney, "Ultimate Shear Strength of Reinforced Concrete Flat Slabs, Footing Beams and Frame Members without Shear Reinforcement," Journal of the American Concrete Institute, vol. 29, no. 4, pp. 265-298, 1957.

[5] J. Moe, "Shearing Strength of Reinforced Concrete Slabs and Footings under Concentrated Load," Bulletin D47, Portland Cement Association Research and Development Laboratories, Skokie, Illinois, USA, 1961, pp. 1-135.

[6] R. I. Gilbert and X. H. Guo, "Time-dependent deflection of reinforced concrete flat slabs- an experimental study," ACI Structural Journal, vol. 102, no. 3, pp. 363-373, May 2005.

[7] E. P. Jokinen and A. Scanlon, "Field measured two-way slab deflections," in Proc. CSCE Annual Conference, Saskaton, Canada, pp. $16,1985$.

[8] J. A. Sbarounis, "Multi-storey flat plate buildings-measured and computed one-year deflections," Concrete International, vol. 6, no. 8, pp. 31-35, August 1984.

[9] Building Code Requirements for Reinforced Concrete, ACI 318-11, American Concrete Institute, Michigan USA, 2011.

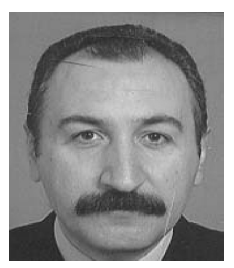

Sevket Ozden recieved his bachelor's and $\mathrm{PhD}$. degrees in civil engineering from Bogazici University, Turkey and his M.S degree from University of Toronto, Canada. His research interest include: behavior of reinforced concrete structures, rehabilitation of cultural heritage, design and assesment of reinforced concrete structures and precast reinforced concrete structures. $\mathrm{He}$ is currently working as Associate Professor at the

Department of Civil Engineering of Okan University in İstanbul.

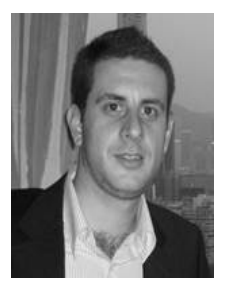

Hakan Erdogan was born in Kocaeli, Turkey 1980. $\mathrm{He}$ recieved his B.S. degree as a civil engineer from Kocaeli University and his Ph.D. degree from Middle East Technical University. He also worked as a visiting researcher at Civil Engineering Department of Florida International University. His research interest includes strengthening and rehabilitation techniques of existing structures, punching behavior of flat-plates and finite element analysis of reinforced concrete structures. $\mathrm{He}$ is currently working as Research Assistant at the Department of Civil Engineering of Kocaeli University.

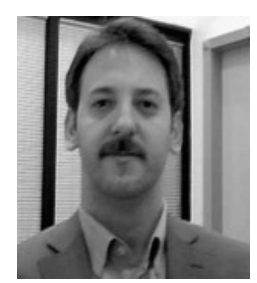

Erkan Akpinar has his bachelor in civil engineering in 2001 from Kocaeli University, Turkey. He has his MSc and PhD degrees in 2004 and 2010 respectively from Kocaeli University, Turkey. He studied in University of Ottawa, Canada as a visiting researcher between 2009 and 2010. His areas of interest are behavior of reinforced concrete, masonry and prefabricated structures and strengthening of structures. He is working as Assistant Professor in Kocaeli University, Engineering Faculty, Department of Civil Engineering, Kocaeli, Turkey. 